\title{
Relationship between osteopenic syndrome and severity of coronary artery disease detected with coronary angiography and Gensini score in men
}

This article was published in the following Dove Press journal:

Clinical Interventions in Aging

24 March 2016

Number of times this article has been viewed

\author{
Bircan Alan' \\ Veysi Akpolat ${ }^{2}$ \\ Adem Aktan ${ }^{3}$ \\ Sait Alan ${ }^{3}$ \\ 'Department of Radiology, \\ 2Department of Biophysics, \\ ${ }^{3}$ Department of Cardiology, Dicle \\ University Medical Faculty, Diyarbakır, \\ Turkey
}

Background: Many studies have shown that evidence supporting the relationship between low bone mineral density (BMD) and coronary artery disease (CAD) has been increasing. There is a significant increase of myocardial infarction in men with low BMD.

Purpose: We aimed to detect the relationship between BMD and CAD in patients whose CAD was detected with coronary angiography, and its severity and prevalence was detected with Gensini score.

Methods: A total of 55 patients were selected who were found to have single or multiple infarctions through using coronary angiography in the cardiology clinic. The CAD severity was evaluated by calculating the Gensini score. These patients were divided into two groups: mild CAD and severe CAD groups. Femur bone mineral density (FBMD) was measured with dual energy X-ray absorptiometry. T score values were determined to be normal if the values were $>-1.0(\mathrm{n}=22,40 \%)$, and osteopenia-osteoporosis (osteopenic syndrome) if the $\mathrm{T}$ score values were $\leq-1(n=33,60 \%)$.

Results: The FBMD of severe CAD according to the Gensini risk score was found to be significantly lower. FBMD values in patients decreased as their Gensini scores increased.

Conclusion: There was a significant relationship between $\mathrm{CAD}$ and osteopenic syndrome. FBMD level in men with severe CAD is significantly low when compared with patients who have mild CAD.

Keywords: osteopenic sydrome, osteoporosis, osteopenia severity of coranary artery disease, bone mineral density

\section{Introduction}

Cardiovascular disease (CVD) and osteoporosis are common in the population. They are one of the highest causes of mortality and morbidity, which increases with age. In recent years, evidence supporting the relationship between low bone mineral density (BMD) and CVD has been increasing. In studies, it has been reported that arterial calcification could be actively regulated not only with age, but also with biological mechanisms similar to bone formation. ${ }^{1,2}$ Hydroxyapatite is the main component of the bone mineral phase and also a mineral that can be found in the bone deposits of plaques. ${ }^{3}$ In addition to this pathophysiological evidence, genetic evidence has also been reported that calcified plaques consist of some bone matrix proteins such as Gla protein, bone morphogenetic protein-2, osteopontin, osteocalcin, and collagen. ${ }^{4-7}$

Furthermore, CVD and osteoporosis have some common risk factors. The risk factors include lack of estrogen, parathyroid hormone, homocysteine, lipid oxidation
Correspondence: Bircan Alan Department of Radiology, Dicle University Medical Faculty, Silvan Street, 21280 , Diyarbakır, Turkey

Tel +90 4I205324421950

Fax +90 4I 2488523

Email bircanalan@hotmail.com
Clinical Interventions in Aging 20 | 6: | I 377-382

377

Dovepress

http://dx.doi.org/1 $0.2147 / C \mid A . S 104036$ (c) (1) (2) 2016 Alan et al. This work is published and licensed by Dove Medical Press Limited. The full terms of this license are available at https://www.dovepress.com/terms.php
and incorporate the Creative Commons Attribution - Non Commercial (unported, v3.0) License (http://creativecommons.org/licenses/by-nc/3.0/). By accessing the work you hereby accept the Terms. Non-commercial uses of the work are permitted without any furcher permission from Dove Medical Press Limited, provided the work is properly attributed. For permission hereby accept the Terms. Non-commercial uses of the work are permitted without any further permission from Dove Medions.
for commercial use of this work, please see paragraphs 4.2 and 5 of our Terms (https://www.dovepress.com/terms.php). 
products, inflammatory process, vitamins D and $\mathrm{K}$, similar molecular pathways involved in bone and vascular mineralization, and calcification mechanisms that seem to be similar in vascular structure and bone. ${ }^{8}$

Atherosclerotic vascular disease is more common in women with osteoporosis and osteopenia when compared with women without osteoporosis and osteopenia. ${ }^{9}$ An increase in mortality rates related with CVD in advanced ages has been reported for postmenopausal women with low bone mineral content. ${ }^{10}$ There is an insignificant increase of myocardial infarction with a rate of $22 \%$ in women with low $\mathrm{BMD}$, while there is a significant increase of myocardial infarction with a rate of $39 \%$ in men with low BMD. ${ }^{11}$

CVD and BMD were compared in terms of coronary angiography and calcium score in the recent studies. ${ }^{8,10,11}$ In this study, we aimed to determine prevalence and severity of coronary artery disease (CAD) using coronary angiography and Gensini scoring, as well as to detect its relation with BMD.

\section{Methods}

A total of 78 male patients who were admitted to the cardiology clinic with chest pain between August 2014 and January 2015 were included in the study. After coronary angiography, a total of 55 male patients (age; 62.1 \pm , range 55-83) with CAD were included into the study. Twenty patients with normal coronary angiography and three patients under 55 years of age were excluded. Moreover, female patients, patients under 55 years of age, patients with moderate and severe heart valve disease, decompensated heart failure, those with severe kidney or liver failure, those with any malignancy, patients with hematological diseases, patients who had autoimmune disorder, patients who were taking steroid treatment and patients with vitamin D deficiency (25[OH]D levels $<20 \mathrm{ng} / \mathrm{mL}$ ) were excluded. Risk factor information about the patients was taken through a standardized interview. Diabetes mellitus type 2 diagnosis was made according to World Health Organization (WHO) criteria. Patients with a hypertension diagnosis (whose diagnosis was made by a doctor and/or patients who were taking antihypertensive drug treatment) were recorded.

Height and weight were recorded. In addition, body mass index (BMI) was calculated as body weight $(\mathrm{kg}) / \mathrm{height}$ square $(\mathrm{m})$.

Ethical approval was obtained from Dicle University Medical Faculty ethics committee for noninterventional studies and voluntary written informed consent were taken for the study.

\section{Coronary angiograms and Gensini risk scoring}

Selective coronary angiography was applied to all patients with Judkins technique. Angiograms were recorded in multiple projections with a biplanar digital cardiac imaging system (Philips Integris DCI, Eindhoven, the Netherlands). Cine angiograms were evaluated by two experienced cardiologists. By examining all of the coronary angiograms, the localization and luminal stenosis rate of all coronary artery lesions were identified. According to the American College of Cardiology/ American Heart Association (ACC/AHA) lesion classification, at least $50 \%$ stenosis in the arterial vessel diameter of any major coronary artery is defined as CAD. ${ }^{12}$ The Gensini scoring system was used in defining CAD severity. ${ }^{13}$ This method scores the extent and degree of coronary artery stenosis in addition to classifying it. First, in this system, stenosis between $1 \%$ and $25 \%$ is 1 point, stenosis between $26 \%$ and $50 \%$ is 2 points, stenosis between $51 \%$ and $75 \%$ is 4 points, stenosis between $76 \%$ and $90 \%$ is 8 points, stenosis between $91 \%$ and $99 \%$ is 16 points, and total occlusion is scored as 32 points. Then, this score is multiplied with a factor that shows the importance of the localization of lesion in the coronary arterial system. For localization, scores are multiplied by 5 for the left main coronary, 2.5 for the proximal left anterior descending (LAD) and left circumflex (LCX), 1.5 for the mid segment LAD and LCX, 1 for the distal segment of LAD and LCX, first diagonal branch, first obtuse marginal branch, right coronary artery, posterior descending artery and intermediate arteries, and 0.5 for the second diagonal and second obtuse marginal branches. After obtaining the Gensini score for the patients with $\mathrm{CAD}$, receiver operating characteristic (ROC) analysis was conducted and the cut-off values were defined. CAD patients were divided into two groups: below the cut-off value and above the cut-off value. The first group was composed of those with mild atherosclerosis (Gensini score $<25$ points [mild CAD group]) while the second group was composed of those with severe atherosclerosis (Gensini score $\geq 25$ points [severe CAD group]), and this grouping is compatible with the literature. ${ }^{14}$

\section{BMD measurement}

A BMD measurement was made on the same day as discharge, to the patients who had coronary angiography and stenosis above $50 \%$ in at least one of their coronary arteries. The BMD (grams per square centimeter) measurement was made by using dual energy X-ray absorptiometry (QDR 4500A Discovery, Hogic, Waltham, USA) from the femoral neck and total proximal femoral areas (comprising the femoral neck, greater trochanter, and intertrochanter). 
Table I The demographic data of normal BMD and osteopenic syndrome groups in patients with coronary artery disease

\begin{tabular}{|c|c|c|c|}
\hline & $\begin{array}{l}\text { CAD patients with normal } \\
\text { BMD group* }(n=23)\end{array}$ & $\begin{array}{l}\text { CAD patients with osteopenic } \\
\text { syndrome group* }(n=32)\end{array}$ & $P$-value** \\
\hline Age, year (mean $\pm S D)$ & $61.2 \pm 6$ & $67 \pm 11$ & NS \\
\hline $\mathrm{BMI}, \mathrm{kg} / \mathrm{m}^{2}($ mean $\pm \mathrm{SD})$ & $27 \pm 3$ & $28 \pm 5$ & NS \\
\hline Total cholesterol mg/dL (mean \pm SD) & $183 \pm 42$ & $184 \pm 33$ & NS \\
\hline Triglyceride, $\mathrm{mg} / \mathrm{dL}($ mean $\pm \mathrm{SD})$ & $20 I \pm 2 I$ & $161 \pm 18$ & NS \\
\hline $\mathrm{HDL}$, cholesterol mg/dL (mean $\pm \mathrm{SD})$ & $35 \pm 7$ & $35 \pm 5$ & NS \\
\hline LDL, cholesterol mg/dL (mean \pm SD) & $114 \pm 17$ & $116 \pm 25$ & NS \\
\hline Serum calcium, mg/dL & $9 \pm 2$ & $8.9 \pm 2$ & NS \\
\hline Serum phosphorus, mg/dL & $4.3 \pm 1$ & $4.4 \pm 1$ & NS \\
\hline $25(\mathrm{OH}) \mathrm{D}, \mathrm{ng} / \mathrm{mL}$ & $38 \pm 6$ & $35.8 \pm 10$ & NS \\
\hline Hypertension (n, \%) & $20(83.3)$ & $21(65.6)$ & NS \\
\hline Diabetes mellitus (n, \%) & $12(52,1)$ & $13(38.2)$ & NS \\
\hline Smoking (n, \%) & $12(50)$ & II (34.3) & NS \\
\hline
\end{tabular}

Notes: *Values are mean \pm SD or $\mathrm{n}(\%)$; **Mann-Whitney U-test.

Abbreviations: BMD, bone mineral density; BMI, body mass index; CAD, coronary artery disease; HDL, high-density lipoprotein; LDL, low-density lipoprotein; 25(OH)D, 25-hydroxyvitamin D; NS, not significant; SD, standard deviation.

Our patients were older, because of the high prevalence of degenerative lesions in older ages, incorrect measurements may result in the lumbar spine, to avoid possible this situation the BMD measurement was made from the femoral neck. The BMD results of these patients were divided into two groups according to WHO criteria: normal ( $\mathrm{T}$ score values $>-1.0$ standard deviation $[\mathrm{SD}][\mathrm{CAD}$ patients with normal BMD group]) and osteopenia-osteoporosis (T score values $\leq-1$ SD [CAD patients with osteopenic syndrome (OS) group]) for males who were over 55 years of age. The osteopenia-osteoporosis group was composed of those with OS. ${ }^{15}$

\section{Statistical analyses}

To analyze the study results statistically, SPSS (Statistical Package for Social Sciences; SPSS Inc., Chicago, IL, USA) Windows 13.0 program was used. The quantitative data are indicated as mean $\pm \mathrm{SD}$. The Kolmogorov-Smirnov test was used for the compatibility of normal distribution of the data. In the comparison of the groups, the Mann-Whitney $U$-test was used in analyzing nonparametric data, while the Student's $t$-test was used for parametric data. The chi-square test was used for categorical data. Spearman and Pearson correlation tests were used in analyzing the relationship between the Gensini scores and the parameters. The specificity and sensitivity for the Gensini score to evaluate the BMD were determined with ROC analysis. $P$-values, $<0.05$ are accepted to be significant for all variables.

\section{Results}

Of 55 male patients whose CAD was proven with angiography, 22 (40\%) had normal BMD (CAD patients with normal BMD group, age: 61.2 \pm 6 , range: $55-81)$ and 33 had $(60 \%)$ OS (CAD patients with OS group, age: $67 \pm 11$, range: $55-83)$.

The demographic data of CAD patients with normal BMD group and CAD patients with OS group are presented in Table 1. Between the normal BMD and OS groups, there is no significant difference according to age, BMI, total cholesterol, triglycerides, high density lipoprotein (HDL), low density lipoprotein (LDL), serum $\mathrm{Ca}$, $\mathrm{P}$, and 25(OH)D levels. Furthermore, these two groups are similar according to hypertension, diabetes mellitus, and smoking.

The results of ROC curve analyses to predict severe and mild CAD based on Gensini score were moderate with area under ROC curve (AUC; 95\% CI=0.711 (0.553-0.873) (Figure 1).

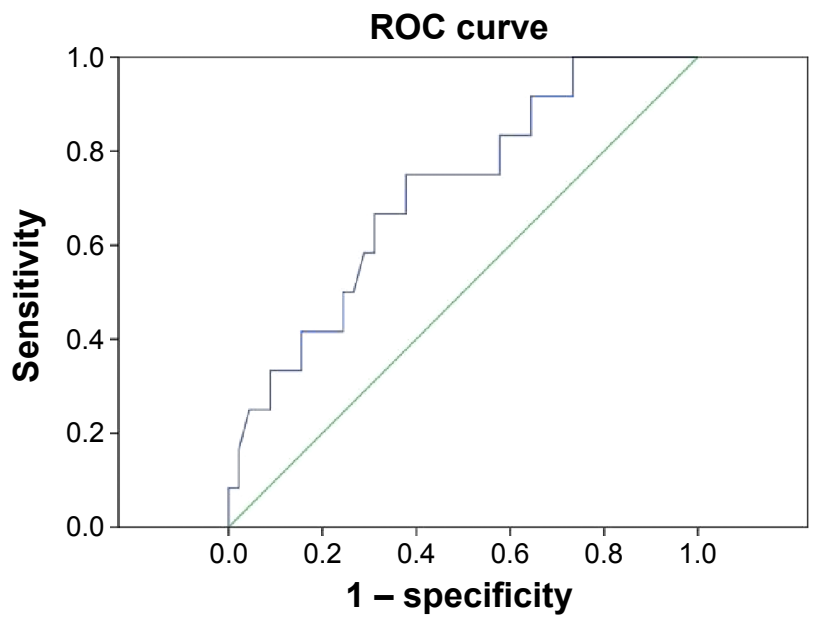

Figure I The receiver operating characteristic (ROC) analysis for Gensini score in patients with coronary artery disease. 
Table 2 Comparison of bone mineral density of patients with severe coronary artery disease to those with mild coronary artery disease according to Gensini score

\begin{tabular}{|c|c|c|c|}
\hline & $\begin{array}{l}\text { Gensini score }<25 * \\
\text { (mild CAD group) }\end{array}$ & $\begin{array}{l}\text { Gensini score } \geq 25^{*} \\
\text { (severe CAD group) }\end{array}$ & $P$-value*** \\
\hline & $n=12$ & $n=43$ & \\
\hline Age, year (mean $\pm S D)$ & $58 \pm 3(55-73)$ & $60 \pm 4(55-83)$ & NS \\
\hline $\begin{array}{l}\text { Coronary vessels involved, } \\
\text { total number }\end{array}$ & I. $2 \pm 0.4(I-2)$ & $1.8 \pm 0.80(I-3)$ & NS \\
\hline FBMD, $\mathrm{g} / \mathrm{cm}^{2}$ & $1.08 \pm 0 \mid(0.92-1.29)$ & $0.97 \pm 0.1(0.55-1.23)$ & 0.02 \\
\hline $25(\mathrm{OH}) \mathrm{D}, \mathrm{ng} / \mathrm{dL}$ & $37.9 \pm 5(33-50)$ & $37.6 \pm 7(22-60)$ & NS \\
\hline
\end{tabular}

Notes: *Values are mean \pm SD (range); **Mann-Whitney U-test.

Abbreviations: CAD, coronary artery disease; FBMD, femur bone mineral density; 25(OH)D, 25-hydroxyvitamin D; NS, not significant; SD, standard deviation.

According to the Gensini risk scoring, $<25$ is evaluated as mild CAD group ( $\mathrm{n}=12$ [age $61 \pm 5$, range: $56-73$ ]) while $\geq 25$ is evaluated as severe CAD group ( $\mathrm{n}=43$ [age $62.4 \pm 8$, range: 55-83]). When BMD values are compared between mild and severe $\mathrm{CAD}$ according to Gensini scoring, there is a significant relationship between the Gensini score and femur bone mineral density (FBMD) values; FBMD values were detected to be significantly low in the severe $\mathrm{CAD}$ group when compared with mild CAD $(P=0.02)$ (Table 2$)$.

A significant relationship was detected in correlation analysis between calculated Gensini risk scoring in coronary artery patients and FBMD $(r=-0.306, P=0.04)$ (Table 3$)$. In coronary artery patients, as Gensini score decreased, FBMD values increased (Figure 2).

Multivariate analysis was performed to determine the effects of age, BMI, 25(OH)D levels, lipid parameters, diabetes mellitus, hypertension, and smoking on the FBMD, but a meaningful relationship was not detected (Tables 4 and 5).

\section{Discussion}

In our study, osteopenia-osteoporosis incidence increases in CAD patients who have severe CAD, according to Gensini scoring, when compared with mild CAD. The relationship between CAD and BMD has been attempted to be proven

Table 3 Correlation analysis between Gensini risk score and age, BMI, coronary vessels involved, FBMD, and 25(OH)D in patients with coronary artery disease

\begin{tabular}{lll}
\hline & R & P-value* $^{*}$ \\
\hline Age, years & 0.74 & NS \\
Coronary vessels involved, total number & 0.247 & NS \\
FBMD & -0.306 & 0.02 \\
BMI, kg/m ${ }^{2}$ & -0.221 & NS \\
25(OH)D, ng/dL & -0.226 & NS \\
\hline
\end{tabular}

Note: *Correlation test.

Abbreviations: BMI, body mass index; FBMD, femur bone mineral density; 25(OH)D, 25-hydroxyvitamin D; NS, not significant. by many earlier studies. In a retrospective study with 209 female CAD patients, $78 \%$ had low BMD while $26 \%$ had normal BMD. ${ }^{16}$ In another study carried out in order to detect the relationship between $\mathrm{CAD}$ and $\mathrm{BMD}$, an association between osteoporosis-osteopenia and obstructive CAD was found. ${ }^{17}$ In a retrospective study involving a total of 2,235 elderly patients, the prevalence of CAD in patients with low BMD was determined to be significantly higher than those without osteoporosis..$^{18}$ In a prospective study of women who were 65 years old or above with similar femoral neck BMD, mortality due to CAD was found to be 1.3 times greater when risk factors such as hypertension, diabetes, smoking, older age, and lower physical activity were adjusted. ${ }^{19}$ In our study, BMDs especially in the left femoral neck measurements in CAD patients were low, which is consistent with the existing literature.

According to Gensini scoring, which determines CAD severity, in severe CAD (Gensini score $\geq 25$ ), there was an increase in the osteoporosis-osteopenia rate, while in mild

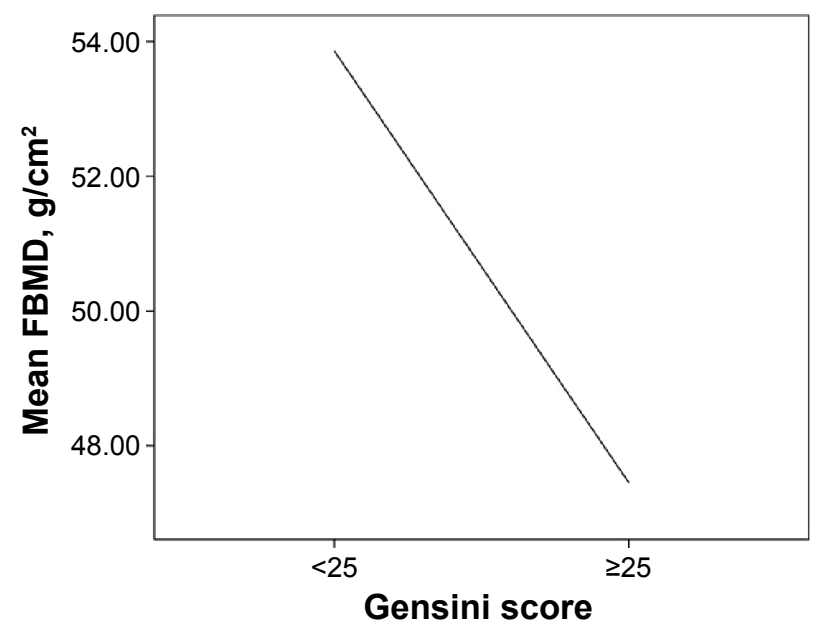

Figure 2 Relationship between Gensini score and bone mineral density in patients with coronary artery disease.

Abbreviation: FBMD, femur bone mineral density. 
Table 4 Detecting the effect of age, BMI, lipid parameters and $25(\mathrm{OH}) \mathrm{D}$ on the FBMD by multivariate analysis

\begin{tabular}{|c|c|c|c|c|c|c|}
\hline \multicolumn{2}{|c|}{ Model } & \multicolumn{3}{|c|}{ Coefficients $^{a}$} & \multirow[t]{3}{*}{$t$} & \multirow[t]{3}{*}{ Sig } \\
\hline & & \multicolumn{2}{|c|}{$\begin{array}{l}\text { Unstandardized } \\
\text { coefficients }\end{array}$} & \multirow{2}{*}{$\begin{array}{l}\text { Standardized } \\
\text { coefficients } \\
\text { Beta }\end{array}$} & & \\
\hline & & B & Std error & & & \\
\hline \multirow[t]{8}{*}{ I } & (Constant) & 1.056 & 0.282 & & 3.744 & 0.001 \\
\hline & Age, year & -0.003 & 0.002 & -0.203 & -1.253 & 0.217 \\
\hline & BMI, $\mathrm{kg} / \mathrm{m}^{2}$ & 0.005 & 0.006 & 0.119 & 0.738 & 0.464 \\
\hline & Triglyceride, $\mathrm{mg} / \mathrm{dL}$ & 0.000 & 0.001 & -0.111 & -0.298 & 0.767 \\
\hline & Total cholesterol mg/dL & 0.000 & 0.002 & 0.106 & 0.171 & 0.865 \\
\hline & LDL, cholesterol mg/dL & -0.001 & 0.002 & -0.240 & -0.475 & 0.637 \\
\hline & $\mathrm{HDL}$, cholesterol mg/dL & 0.002 & 0.004 & 0.085 & 0.429 & 0.670 \\
\hline & $25(\mathrm{OH}) \mathrm{D}, \mathrm{ng} / \mathrm{dL}$ & -0.001 & 0.004 & -0.031 & -0.168 & 0.867 \\
\hline
\end{tabular}

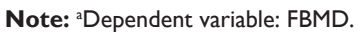

Abbreviations: BMD, bone mineral density; BMI, body mass index; FBMD, femur bone mineral density; HDL, high-density lipoprotein; LDL, low-density lipoprotein; 25(OH)D, 25-hydroxyvitamin D; Std; standard, Sig; significant.

CAD patients (Gensini score $<25$ ) the decrease in BMD was detected to be less. Similarly, in a study with 74 male patients, in which CAD severity was determined by syntax score, severe coronary artery lesions were associated with decreased BMD. ${ }^{20}$ In the present study, there was a significant correlation between Gensini risk scoring in coronary artery patients and FBMD; there was no effects of age, BMI, 25(OH)D, lipid parameters, diabetes mellitus, hypertension, and smoking on the FBMD in multivariate analysis. In another study in which a correlation between atherosclerosis and low BMD in male was defined, it was shown that as severity of calcified carotid artery plaque increased, BMD level decreased. ${ }^{21}$

Although many hypotheses were put forward in order to explain the existence of the relationship existing between CAD and osteoporosis independently of aging, it has not yet been fully understood. Despite common risk factors of cardiovascular risk and bone metabolism (dyslipidemia, oxidative stress, inflammation, hyperhomocystinemia, hypertension, and diabetes mellitus), there can be involvement of many biochemical, molecular, and cellular processes. It has been suggested that atherosclerosis may cause osteoporosis

Table 5 Detecting the effect of smoking, diabetes mellitus and hypertension on the FBMD by multivariate analysis

\begin{tabular}{|c|c|c|c|c|c|}
\hline \multirow[t]{3}{*}{ Model } & \multicolumn{3}{|c|}{ Coefficients $^{a}$} & \multirow[t]{3}{*}{$t$} & \multirow[t]{3}{*}{ Sig } \\
\hline & \multicolumn{2}{|c|}{$\begin{array}{l}\text { Unstandardized } \\
\text { coefficients }\end{array}$} & \multirow{2}{*}{$\begin{array}{l}\text { Standardized } \\
\text { coefficients } \\
\text { Beta }\end{array}$} & & \\
\hline & B & Std error & & & \\
\hline \multirow{4}{*}{$\begin{array}{l}\text { I (Constant) } \\
\text { Smoking } \\
\text { Diabetes mellitus } \\
\text { Hypertension }\end{array}$} & 0.908 & 0.043 & & 21.364 & 0.000 \\
\hline & 0.066 & 0.040 & 0.218 & 1.657 & 0.103 \\
\hline & 0.019 & 0.041 & 0.062 & 0.450 & 0.654 \\
\hline & 0.070 & 0.046 & 0.206 & 1.513 & 0.136 \\
\hline
\end{tabular}

Note: ${ }^{a}$ Dependent variable: FBMD.

Abbreviations: FBMD, femur bone mineral density; Std; standard, Sig; significant. due to a decrease in blood flow of the lower extremities that can cause some changes in the metabolism of hip bones. ${ }^{22}$ Similarly, in a study carried out, a subclinical CVD association was detected with severe osteoporosis of the hip. ${ }^{23}$ It is important that detection of a decrease in total FBMD in our study is similar to these studies.

However, available studies have reported no association between CVD and osteoporosis. ${ }^{24,25}$ In another study, an association between osteoporosis, atherosclerosis, and aging in postmenopausal women and men has been highlighted. Furthermore, when factors like age, smoking, diabetes mellitus, hypertension, and hypercholesterolemia are controlled, these processes are reported to be independent. ${ }^{26}$

\section{Study limitations}

The most important limitation of our study is that the sample size of the study is small. Since this research is a pilot study, it needs to be supported through more extensive studies involving a large series of patients in order to establish the relationship between CAD severity and osteopenia-osteoporosis quantity more accurately. In addition, in a younger group of patients with CAD, carrying out similar studies would help determine the relationship between CAD severity and osteopenic syndrome independent of age factor.

\section{Conclusion}

We determined a significant relationship between CAD and OS in patients in whom there was no significant relationship between age and risk factors. In addition, according to Gensini score, as the CAD severity increased, BMD level was observed to have decreased; also, we are of the opinion that carrying out this and similar studies will contribute considerably to the literature. 


\section{Acknowledgment}

There was no outside financial support or other financial or personal relationships associated with this study.

\section{Disclosure}

The authors report no conflicts of interest in this work.

\section{References}

1. Sinnott B, Syed I, Sevrukov A, Barengolts E. Coronary calcification and osteoporosis in men and postmenopausal women are independent processes associated with aging. Calcif Tissue Int. 2006;78:195-202.

2. Bakhireva LN, Barrett-Connor EL, Laughlin GA, Kritz-Silverstein D. Differences in association of bone mineral density with coronary artery calcification in men and women: the Rancho Bernardo Study. Menopause. 2005;12:691-698.

3. Schmid K, McSharry WO, Pameijer CH, Binette JP. Chemical and physicochemical studies on the mineral deposits of the human atherosclerotic aorta. Atherosclerosis. 1980;37:199-210.

4. Shanahan CM, Cary NR, Metcalfe JC, et al. High expression of genes for calcification-regulating proteins in human atherosclerotic plaques. J Clin Invest. 1994;93:2393-2402.

5. Boström K, Watson KE, Horn S, Wortham C, Herman IM, Demer LL. Bone morphogenetic protein expression in human atherosclerotic lesions. J Clin Invest. 1993;91:1800-1809.

6. Giachelli CM, Bae N, Almeida M, Denhardt DT, Alpers CE, Schwartz SM. Osteopontin is elevated during neointima formation in rat arteries and is a novel component of human atherosclerotic plaques. J Clin Invest. 1993;92:1686-1696.

7. Dhore CR, Cleutjens JP, Lutgens E, et al. Differential expression of bone matrix regulatory proteins in human atherosclerotic plaques. Arterioscler Thromb Vasc Biol. 2001;21:1998-2003.

8. Anagnostis P, Karagiannis A, Kakafika AI, Tziomalos K, Athyros VG, Mikhailidis DP. Atherosclerosis and osteoporosis: age-dependent degenerative processes or related entities? Osteoporos Int. 2009; 20:197-207.

9. Ness J, Aronow WS. Comparison of prevalence of atherosclerotic vascular disease in postmenopausal women with osteoporosis or osteopenia versus without osteoporosis or osteopenia. Am J Cardiol. 2006; 97:1427-1428.

10. Von der Recke P, Hansen MA, Hassager C. The association between low bone mass at the menopause and cardiovascular mortality. Am J Med. 1999; 106:273-278.

11. Magnus JH, Broussard DL. Relationship between bone mineral density and myocardial infarction in US adults. Osteoporos Int. 2005;16: 2053-2062.
12. Ryan TJ, Faxon DP, Gunnar RM, et al. Guidelines for percutaneous transluminal coronary angioplasty. A report of the American College of Cardiology/American Heart Association Task Force on Assessment of Diagnostic and Therapeutic Cardiovascular Procedures (Subcommittee on Percutaneous Transluminal Coronary Angioplasty). Circulation. 1988; 78:486-502.

13. Gensini GG. A more meaningful scoring system for determining the severity of coronary heart disease. Am J Cardiol. 1983;51:606.

14. Oishi Y, Wakatsuki T, Nishikado A, Oki T, Ito S. Circulating adhesion molecules and severity of coronary atherosclerosis. Coron Artery Dis. 2000;11:77-81.

15. Prevention and management of osteoporosis. World Health Organ Tech Rep Ser. 2003;921:1-164.

16. Marcovitz PA, Tran HH, Franklin BA, et al. Usefulness of bone mineral density to predict significant coronary artery disease. Am J Cardiol. 2005;96:1059-1063.

17. Varma R, Aronow WS, Basis Y, et al. Relation of bone mineral density to frequency of coronary heart disease. Am J Cardiol. 2008;101: 1103-1104.

18. Yesil Y, Ulger Z, Halil M, et al. Coexistence of osteoporosis (OP) and coronary artery disease (CAD) in the elderly: it is not just a by chance event. Arch Gerontol Geriatr. 2012;54:473-476.

19. Kado DM, Browner WS, Blackwell T, Gore R, Cummings SR. Rate of bone loss is associated with mortality in older women: a prospective study. J Bone Miner Res. 2000;15:1974-1980.

20. Kokov AN, Maliuta EB, Masenko VL, et al. [Evaluation of coronary artery lesion in men with osteopenic syndrome and coronary artery disease]. Ter Arkh. 2014;86:65-70. Russian.

21. Jørgensen L, Joakimsen O, Mathiesen EB, et al. Carotid plaque echogenicity and risk of nonvertebral fractures in women: a longitudinal population-based study. Calcif Tissue Int. 2006;79:207-213.

22. Farhat GN, Cauley JA, Matthews KA, et al. Volumetric BMD and vascular calcification in middle-aged women: the Study of Women's Health Across the Nation. J Bone Miner Res. 2006;21:1839-1846.

23. Tankò LB, Bagger YZ, Christiansen C. Low bone mineral density in the hip as a marker of advanced atherosclerosis in elderly women. Calcif Tissue Int. 2003;73:15-20.

24. Hyder JA, Allison MA, Criqui MH, Wright CM. Association between systemic calcified atherosclerosis and bone density. Calcif Tissue Int. 2007;80:301-306.

25. Aoyagi K, Ross PD, Orloff J, Davis JW, Katagiri H, Wasnich RD. Low bone density is not associated with aortic calcification. Calcif Tissue Int. 2001;69:20-24.

26. Sinnott B, Syed I, Sevrukov A, Barengolts E. Coronary calcification and osteoporosis in men and postmenopausal women are independent processes associated with aging. Calcif Tissue Int. 2006;78:195-202.
Clinical Interventions in Aging

\section{Publish your work in this journal}

Clinical Interventions in Aging is an international, peer-reviewed journal focusing on evidence-based reports on the value or lack thereof of treatments intended to prevent or delay the onset of maladaptive correlates of aging in human beings. This journal is indexed on PubMed Central, MedLine,

\section{Dovepress}

CAS, Scopus and the Elsevier Bibliographic databases. The manuscript management system is completely online and includes a very quick and fair peer-review system, which is all easy to use. Visit http://www.dovepress. com/testimonials.php to read real quotes from published authors. 